\title{
Isolation of Keratinophilic Fungi from Soil in Khairpur City, Sindh, Pakistan
}

\author{
Irshad Hussain Soomro*, Yasmeen Faiz Kazi, Miandad Zardari and Abdul Hussain Shar \\ Department of Microbiology, Shah Abdul Latif University Khairpur, Sindh, Pakistan
}

[Received 02 February 2007; Accepted 21 April 2007]

\begin{abstract}
One hundred and twenty five soil samples were collected from five areas in the vicinity of Khairpur city, Sindh, Pakistan and screened for the presence of keratinophilic fungi by using hair bait technique. A total 253 isolates belonged to eight genera and eleven species of keratinophilic fungi were recovered. Maximum number (153/253, 60.5\%) of keratinophilic fungi was recovered from farm land and poultry soils. Aspergillus niger was most prevalent species and represented $20.2 \%$ of the total number isolated. A. flavus and A. fumigatus were almost equal in their prevalence and represented 11.9 and $\mathbf{1 1 . 1} \%$, respectively. Botrytis cinaria comes next constituting 9.9\%; followed by Mucor spp. (9.1\%) and Chochliobolus lunatus (8.3\%). Other species isolated less frequently included Chrysosporum asperatum (5.9\%), Fusarium spp. (5.1\%), Penicillium spp. (3.1\%) and A. wentii $(2.4 \%)$. The distribution pattern of the different keratinophilic fungi and their significance are discussed.
\end{abstract}

Keywords: Keratinophilic fungi, Prevalence, Keratinase, Hair bait technique

Keratinophilic fungi like to grow and even reproduce on keratin materials such as skin, hair, nail, fur, feather, horn, hoof beak of the birds etc. They utilize keratin as carbon source ${ }^{1}$. Keratin is highly insoluble protein having fibrous helical structure and numerous disulfide linkages which make it resistant to many proteases but is easily digested by keratinase enzymes ${ }^{2}$.

The keratineous materials in or on soil are attacked by these keratinophilic microbes, therefore biodegradation takes place. Keratinases also provide the virulence to certain fungi such as dermatophytes to cause dermatophytoses or ringworm in human and animals ${ }^{3-4}$. These enzymes, on the other hand, have immense effect on prion which causes bovine spongy encephalitis (BSE) commonly known as 'mad cow' disease because these enzymes successfully digested and removed the prion from diseased tissue of brain ${ }^{5}$. There are also other applications of keratinases in various industries such as leather, poultry, cosmetics, diagnostics, and pharmaceuticals ${ }^{6-9}$.

Keeping in view such enormous significance of keratinophilic fungi for keratinase enzymes production, the present study was under taken to isolate these microorganisms from fertile soils, animal herds, animal slaughter houses, poultries and barbers' shops. A total 125 soil samples were collected from five different sources including fertile lands, animal herds, animal slaughter houses, poultries and barbers' shops in Khairpur city, Sindh, Pakistan. From each sources 25 soil samples were collected and screened for keratinphilic fungi by employing hair bait technique using human hair as keratin bait ${ }^{10-17}$. Invaded hairs were inoculated on Sabourauds dextrose agar (SDA) supplemented with chloramphenicol $0.05 \mathrm{mg} / \mathrm{l}$ for obtaining the cultural growth. Cultures were purified and maintained on potato dextrose agar $(\mathrm{PDA})$ at $5^{\circ} \mathrm{C}$. The identification of isolates was made as per Dexter ${ }^{3}$ and Domesck et al. ${ }^{1}$.

The results of the isolation of keratinophilic fungi are presented in Table 1. The data revealed that of 125 samples, maximum number (85/253; 33.6\%) of keratinophilic fungi was isolated from soils of fertile lands; followed by the soil samples from poultries (68/253; $26.9 \%)$. Isolation rates of keratinophilic fungi from soils of animal herd (44/253; 17.4\%) and barbers' shops (43/253; 17.0\%) were almost similar. The least number of keratinophilic fungi was isolated from the slaughter house soils (13/253; 5.1\%).

A total of 253 keratinophilic fungi including eight genera and eleven species were isolated, viz., Aspergillus niger (20.2\%), Alternaria alternata (13.0\%), Aspergillus flavus (11.9\%), Aspergillus fumigatus (11.1\%), Botrytis cinaria (18.2\%), Chochliobolus lunatus (16.8\%), Mucor spp.(16.0\%), Chrysosporum asperatum (9.9\%), Fusarium spp. (5.1\%), Penicillium spp. (3.1\%) and Aspergillus wentii (2.4\%) (Table 1). Aspergillus accounted for $45.6 \%$ distribution, with A. niger being the dominant species. It is interesting that some fungi isolated in this study such as Aspergillus, Alternaria, Chochliobolus, Botrytis, Fusarium and Mucor were previously thought as nonkeratinophilic, but subsequent studies showed that these fungi possess keratinolytic activities when grown on keratin-rich substrates and they also occur in the environment in keratin-rich soils ${ }^{13,15-17}$. Keratinolytic enzymes have been shown to be useful for biotechnological purposes such as hydrolysis of poultry feathers ${ }^{19}$ and dehairing of bovine pelts ${ }^{20}$.

*Corresponding author:

Dr. Irshad Hussain Soomro, Assistant Professor, Department of Microbiology, Shah Abdul Latif University Khairpur, Sindh, Pakistan

Tel (Office): +92 (0243) 9280286; Tel (Home): +92 (0243) 553165; Cell: 03013 428046; E-mail: irshadhussainsoomro@yahoo.com 
Table 1. Isolation rate keratinophilic fungi from various soils collected in Khairpur city

\begin{tabular}{lcccccc}
\hline Keratinophilic fungus & \multicolumn{5}{c}{ Isolation rate, No. (\%) } \\
\cline { 2 - 6 } & $\begin{array}{c}\text { Fertile } \\
\text { land } \\
(\mathrm{n}=25)\end{array}$ & $\begin{array}{c}\text { Animal } \\
\text { herd } \\
(\mathrm{n}=25)\end{array}$ & $\begin{array}{c}\text { Slaughter } \\
\text { house } \\
(\mathrm{n}=25)\end{array}$ & $\begin{array}{c}\text { Poultry } \\
(\mathrm{n}=25)\end{array}$ & $\begin{array}{c}\text { Barbers’ } \\
\text { shop } \\
(\mathrm{n}=25)\end{array}$ & Total \\
$(\mathrm{n}=125)$ \\
\hline Alternaria alternata & $8(32)$ & $2(8)$ & $1(4)$ & $13(52)$ & $9(36)$ & $33(13.0)$ \\
Aspergillus niger & $15(60)$ & $7(28)$ & $2(8)$ & $18(72)$ & $9(36)$ & $51(20.2)$ \\
Aspergillus flavus & $10(40)$ & $4(16)$ & $1(4)$ & $5(20)$ & $10(40)$ & $30(11.9)$ \\
Aspergillus fumigatus & $10(40)$ & $3(12)$ & $0(0)$ & $11(44)$ & $4(16)$ & $28(11.1)$ \\
Aspergillus wentii & $3(12)$ & $1(4)$ & $0(0)$ & $2(8)$ & $0(0)$ & $6(2.4)$ \\
Botrytis cinaria & $10(40)$ & $7(28)$ & $0(0)$ & $5(20)$ & $3(12)$ & $25(9.9)$ \\
Chochliobolus lunatus & $4(16)$ & $6(24)$ & $1(4)$ & $5(20)$ & $5(20)$ & $21(8.3)$ \\
Chrysosporum asperatum & $2(8)$ & $9(36)$ & $3(12)$ & $0(0)$ & $1(4)$ & $15(5.9)$ \\
Fusarium species & $9(36)$ & $1(4)$ & $1(4)$ & $2(8)$ & $0(0)$ & $13(5.1)$ \\
Mucor species & $11(44)$ & $4(16)$ & $4(16)$ & $3(12)$ & $1(4)$ & $23(9.1)$ \\
Penicillium species & $3(12)$ & $0(0)$ & $0(0)$ & $4(16)$ & $1(4)$ & $8(3.1)$ \\
\hline Total & $85(33.6)$ & $44(17.4)$ & $13(5.1)$ & $68(26.9)$ & $43(17.0)$ & $253(100.0)$ \\
\hline
\end{tabular}

It appears from this study that Aspergillus niger is the most prevalent keratinophilic fungus and also dominant species that isolated from 51 soil samples of five different regions like fertile lands, animal herds, slaughter houses, poultries and barbers' shops. Isolation rate of keratinophilic fungi including $A$. niger was higher in soil samples collected from the farm lands and poultries. Keratinases have enormous potential applications in processing waste in the poultry and leather industries. In this study, some keratinophic fungi were isolated, which could be used for the production of adequate amounts for application in industrial processes.

\section{References}

1. Cooke RC. 1990. Fungi, Man and His Environment, pp 17-19. LongMan Group Ltd, London.

2. Grant WD \& Long PE. 1981. Environmental Microbiology, p 103. Blackie \& Son Ltd, Glasgow.

3. Dexter HH. 1983. Ascomycetes: The Dermatophytes. In Fungi Pathogenic for Human and Animals, pp 128-129, 335. Mercel Dekker Inc, New York.

4. Fry L \& Cornell MNP. 1985. Dermatology, p 13. PSG Publication Co, Littleton, Mass.

5. Langeveld JP, Wang JJ, Van de Wiel DF, Shih GC, Garssen GJ, Bossers A \& Shih JC. 2003. Enzymatic degradation of prion protein in brain stem from infected cattle and sheep. J Infect Dis. 188(11): 1782-1789.

6. Lin X, Lee CG, Casale ES \& Shih JCH. 1995. Purification and characterization of a keratinase from a feather-degrading Bacillus licheniformis strain. Appl Environ Microbiol. 58(10): 3271-3275.

7. Raju AA, Chandrababu NK, Samivelu N, Rose C \& Rao NM. 1996. Eco-friendly enzymatic dehairing using extracellular proteases from a Bacillus species isolate. J Am Leather Chem Assoc. 91(5): 115-119.

8. Williams CM, Lee CG, Garlich JD \& Shih JCH. 1991. Evaluation of a bacterial feather fermentation product, feather-lysate, as a feed protein. Poultry Sci. 70(1): 85-94.
9. Dalev P \& Neitchev V. 1991. Reactivity of alkaline proteinase to keratin and collagen containing substances. Appl Biochem Biotechnol. 27(2): 131-138.

10. Punsola L \& Guarrow J. 1984. Distribution of mating types of the Microsporum gypseum complex in Spanish soil. Mycopathologia. 85: $185-90$.

11. Jain M, Shukla PK \& Srivastava OP. 1985. Keratinophilic fungi and dermatophytes in Lukhnow soil and their global distribution. Mykosen. 28(2): 148-153.

12. Oghonna CLC \& Pugh GJF. 1987. Keratinophilic fungi from Nigerian soil. Mycopathologia. 99(2): 115-118.

13. Mercantini R, Marsella \& Carvallari MC. 1989. Keratinophilic fungi isolated from Antartic soil. Mycopathologia. 106(1): 47-52.

14. Soomro IH, Zardari M, Abro H \& Mangi S. 1990. Isolation and identification of dermatophytes and other keratinophilic fungi from soil of Shah Abdul Latif University Khairpur, Sindh, Pakistan. Scientific Khyber. 3(2): 175-182.

15. Soomro IH \& Zardari M. 1996. Recovery of keratinophilic fungi from soil and their relation with some ecological factors in Khairpur, Sindh, Pakistan. Sci Sindh. 3: 203-221.

16. Soomro IH \& Zardari M. 2002. Investigation keratinophilic fungi from saline soil in Khairpur, Sindh, Pakistan. Hamdard Medicus. 46: 82-85.

17. Soomro IH, Zardari M, Kazi YF \& Shahani NK. 2006. Hair bait technique: A method for isolation of keratinase producing microorganisms from soil. Hamdard Medicus. 49(1): 49-52.

18. Domesch KH, Games H \& Traut-Heidi A. 1980. Compendium of Soil Fungi, Vol 1, pp 66, 194, 420. Academic Press. London.

19. Riffel A, Lucas FS, Heeb P \& Brandelli A. 2003. Characterization of a new keratinolytic bacterium that completely degrades native feather keratin. Arch Microbiol. 179(4): 258-265.

20. Riffel A, Ortolan S \& Brandelli A. 2003. De-hairing activity of extracellular proteases produced by keratinolytic bacteria. $J$ Chem Technol Biotechnol. 78(8): 855-859. 